\title{
Penyusunan Album Keterampilan Hidup Sehari-Hari Untuk Anak Usia 2 - 6 Tahun Berdasar Pada Metode Montessori
}

\author{
Andri Anugrahana \\ andrianugrahana@gmail.com \\ PGSD Universitas Sanata Dharma
}

The Development of Everyday's Living Skill Albums for Children Ages 2 - 6 Years
Based on Montessori Method

\begin{abstract}
This study aims to describe the process of developing a teaching book for daily life skills for children ages 2 - 6 years based on Montessori method. This research uses research and development method, intending to (1) find out the procedure for developing daily life skill albums for children ages 2 - 6 years based on Montessori method and (2) describe the quality of the album. The research and development is modified from ten stages of Sugiyono and Borg and Gall, into five stages: 1) potential problems, 2) product design, 3) product validation by experts, 4) test instruments, and 5) limited trials. The result from expert validation for the purpose and method scored 3.75, considered in 'good' category. The content aspect scords 3, in 'average' category. The content aspect scored 3.5, in 'good' category. Overall, the result of expert validation showed the score of 3,4, and was considered as 'good'.
\end{abstract}

Keywords: Teaching Aid, Life Skills, Montesori Method

Received date: 12 April 2019

Article Info

Revised date: 2 Mei 2019

Accepted date: 20 Mei 2019

\section{PENDAHULUAN}

Pendidikan mempunyai peranan penting dalam mengembangkan sumber daya manusia, agar anak didik menjadi manusia yang berkualitas, profesional, terampil, kreatif dan inovatif. Peran pendidikan dapat mempengaruhi perkembangan fisik, mental, emosional, moral serta keimanan dan ketakwaan manusia (Makmun, 2007). Pemerintah Republik Indonesia telah bertekad untuk memberikan kesempatan kepada seluruh warga negara Indonesia agar memperoleh pendidikan yang berkualitas, sebagai langkah utama dalam meningkatkan taraf hidup masyarakat. Untuk itu, peran pendidik sangat diperlukan dalam mewujudkan misi pendidikan tersebut. Sebagai agen pembaharu, pendidik bertanggung jawab dalam mengembangkan dan mewariskan nilai kepada anak didik yang selanjutnya nilai-nilai tersebut akan diwujudkan dalam kehidupan sehari-hari. Nilai-nilai ketrampilan hdup seharihari dapat mulai ditanamkan sejak usia dini. Putra, Nugroho, dan Puspitarini, (2016) menjelasakan secara umum anak usia dini merupakan anak yang berada pada usia 0-6 tahun. Usia dini merupakan usia yang sangat penting bagi perkembangan anak sehingga sebagai Golden Age. Anak usia dini sedang dalam tahap pertumbuhan dan perkembangan yang paling pesat, baik fisik maupun mental. Anak usia dini belajar dengan caranya sendiri. Bila ditinjau dari hakikat anak usia dini, maka anak memiliki dua aspek perkembangan yaitu biologis dan psikologi. Pada usia Golden Age inilah anak mengalami proses penyerapan. Maria Montessori menyebutnya sebagai the absorbent mind/pikiran yang mudah menyerap. Kemampuan unik ini terjadi selama sejak lahir hingga usia 6 tahun, masa bayi anak menyerap pengalaman dari lingkungan sekitarnya melalui semua inderanya kemudian diolah melalui otak. Melalui proses penyerapan seperti ini, pikiran benar-benar terbentuk. Oleh karena itu, anak secara langsung mengasimilasi lingkungan fisik dan sosial tempat ia berbaur, dan secara simultan mengembangkan kekuatan mental bawaannya. (Elytasari, 2017)

Tuntutan masyarakat yang semakin besar terhadap pendidikan serta kemajuan ilmu pengetahuan dan teknologi, menyebabkan pendidikan tidak mungkin lagi dikelola hanya dengan melalui pola tradisional. Selain tuntutan tersebut, masyarakat menginginkan kebutuhan akan informasi dan komunikasi, yang sangat berpengaruh pada kemajuan di bidang pendidikan. Revolusi ilmu pengetahuan dan teknologi, perubahan masyarakat, pemahaman cara belajar anak, kemajuan media 
komunikasi dan lain sebagainya memberi arah tersendiri bagi kegiatan pendidikan. Perubahan dapat diawali dari anak usia dini, Peaget (Nurgiantoro, 2008) menjelaskan bahwa anak usia 2 sampai 7 tahun sudah mengalami tahap praoperasional dimana anak tidak hanya melakukan aktivitas fisik saja tetapi sudah mulai mencerminkan aktivitas mental seperti belajar bahasa, bermain dan menggambar.

Anak usia dini adalah anak yang kelima indranya sedang berkembang dengan baik maka perlu pembelajaran yang mengembangkan motoriknya. Dewi, Suara, dan Zulaikha (2014) menjelaskan bahwa Kemampuan motorik halus mempunyai peranan yang sangat penting bagi anak. Hal ini karena kemampuan motorik halus adalah kemampuan anak untuk mempelajari ketepatan koordinasi tangan dan mata. Selain itu anak juga mempelajari cara menggerakan pergelangan tangan agar lentur, seperti menggunting kertas dan menganyam dengan kertas. Untuk mendukung perkembangan motorik anak membutuhkan sarana yang mendukung. Amah (2017) keterbatasan pada jumlah dan variasi sarana prasarana bermain dan belajar seperti alat permainan edukatif. Alat permainan edukatif adalah segala sesuatu yang dapat digunakan sebagai sarana atau peralatan untuk bermain yang mengandung nilai edukatif (pendidikan) dan dapat mengembangkan seluruh kemampuan anak. Hal ini juga didukung dari hasil wawancara peneliti pada guru Paud di salah Satu Taman kanak-Kanak di Surakarta, dimana guru menceritakan kesulitan dalam membuat dan menggunakan media pembelajaran di kelas. Guru membutuhkan buku pegangan pengunaan media dan pelatihan pengunaan media yang dapat memberikan stimulus untuk menjadi guru yang kreatif dan inovatif, serta memberikan motivasi bagi guru untuk membuat media.

Penelitian pengembangan ini dimaksudkan untuk memberikan sumbangan yang berguna kepada guru untuk membuat dan menggunakan album dalam pembelajaran di sekolah. Cara Montessori mengembangkan album sesuai dengan kriteria-kriteria dalam pembuatan album. Kriteria tersebut yaitu menarik, mengandung gradasi rangsangan yang rasional, mengandung pengendali kesalahan, memungkinkan anak belajar secara mandiri dan ditambahkan kriteria dalam penelitian yaitu kontekstual. Rumusan masalah untuk penelitian ini adalah : (1) Bagaimana prosedur mengembangkan album ketrampilan hidup sehari-hari (usia 2 - 6 tahun tahun) dengan metode Montessori?, (2) Bagaimana kualitas album ketrampilan hidup sehari-hari (usia 2 - 6 tahun tahun) dengan metode Montessori?.

\section{KAJIAN PUSTAKA Media Pembelajaran}

Mahnun (2012) menyatakan kata "media" berasal dari bahasa Latin "medium" yang berarti "perantara" atau "pengantar". Lebih lanjut, media merupakan sarana penyalur pesan atau informasi belajar yang hendak disampaikan oleh sumber pesan kepada sasaran atau penerima pesan tersebut. Penggunaan media pengajaran dapat membantu pencapaian keberhasilan belajar. Fahlahudin (2014) menjelaskan bahwa media segala sesuatu yang dapat menyalurkan informasi dari sumber informasi kepada penerima informasi. Istilah media ini sangat populer dalam bidang komunikasi. Proses belajar mengajar pada dasarnya juga merupakan proses komunikasi, sehingga media yang digunakan dalam pembelajaran disebut media pembelajaran. Rohani (dalam Hapsari 2017,4) menyatakan media adalah segala bentuk yang dipergunakan untuk proses penyaluran informasi. Menurut Arsyad juga menjelaskan media pembelajaran adalah "segala sesuatu yang dapat digunakan untuk menyampaikan pesan atau informasi dalam proses belajar mengajar sehingga dapat merangsang perhatian dan minat siswa dalam belajar", maka pemakaian media pembelajaran bisa membantu dan memudahkan kegiatan belajar pada anak (Fitriana, Mustikawan \& Julianto, 2015).

Media pembelajaran terdiri atas dua unsur penting, yaitu unsur peralatan atau perangkat keras (hardware) dan unsur pesan yang dibawanya (message/software). Dengan demikian media pembelajaran memerlukan peralatan untuk menyajikan pesan, namun yang terpenting bukanlah peralatan itu, tetapi pesan atau informasi belajar yang dibawakan oleh media tersebut. Perangkat lunak (software) adalah informasi atau bahan ajar itu sendiri yang akan disampaikan kepada siswa, sedangkan perangkat keras (hardware) adalah sarana atau peralatan yang digunakan untuk menyajikan pesan/bahan ajar tersebut. Peran teknologi dan media dalam pembelajaran dibedakan menjadi dua yaitu 1) jika pembelajaran model teacher centered, teknologi dan media digunakan untuk menunjang presentasi dalam pembelajaran, 2) jika pembelajaran model student centered, siswa merupakan 
pengguna utama teknologi dan media tersebut. Hal ini sesuai dengan pernyataan Smaldino, Lowther dan Russel (2008).

Secara umum Umar (2017) menjelaskan peran media dalam pembelajaran, diantaranya sebagai berikut: (1) Memperjelas penyajian pesan dan informasi sehingga dapat memperlancar dan meningkatkan proses dan hasil belajar. (2) Meningkatkan dan mengarahkan perhatian anak sehingga dapat menimbulkan motivasi belajar, interaksi yang lebih langsung antara siswa dan lingkungannya, dan kemungkinan siswa untuk belajar sendiri-sendiri sesuai dengan kemampuan dan minatnya. (3) Mengatasi keterbatasan indera, ruang, dan waktu; (4) Memberikan kesamaan pengalaman kepada siswa tentang peristiwa-peristiwa di lingkungan mereka.

Media pengajaran dapat meningkatkan proses belajar siswa dan diharapkan dapat meningkatkan hasil belajarnya. Alasan mengapa penggunaan media pembelajaran dapat membuat pembelajaran lebih meningkat berhubungan dengan taraf berfikir siswa. Taraf berfikir manusia mengikuti tahap perkembangan dimulai dari berfikir konkrit menuju berfikir abstrak, dimulai dari berfikir sederhana menuju berfikir kompleks. Penggunaan media pembelajaran erat kaitannya dengan tahapan berfikir tersebut, sebab melalui media hal-hal yang abstrak dapat dikonkritkan dan hal-hal yang kompleks dapat disederhanakan.

\section{Montessori}

Salah satu media pembelajaran yang sesuai dengan tahap-tahap perkembangan anak-anak usia 0 sampai 6 tahun yang menekankan fungsi permainan adalah media pembelajaran Montessori. Media atau juga dapat diartikan alat peraga dalam Montessori memiliki empat ciri khusus (Gutek, 2004), yaitu auto-education, auto-corection, menarik, dan bergradasi. Auto-education memiliki maksud bahwa anak akan belajar sendiri menggunakan alat peraga Montessori. Alat peraga Montessori dirancang sesuai dengan perkembangan anak, baik dalam hal perkembangan psikologi maupun fisiknya (Gutek, 2004). Penyesuaian alat peraga dengan perkembangan fisik dan psikologi ditujukan supaya anak dapat belajar secara mandiri. Sebagai contoh adalah alat peraga Montessori tentang perkalian untuk usia 9 tahun dirancang dengan menggunakan manik-manik untuk mengkonkritkan materi perkalian. Penggunaan manik ditujukan untuk mengkonkritkan materi perkalian karena anak usia 9 tahun ada pada tahapan operasional konkrit. Contoh konsep alat peraga sesuai dengan tahapan fisik anak adalah setiap alat peraga dibuat menggunakan bahan yang ringan. Hal itu ditujukan supaya anak mampu membawanya sendiri.

Karakteristik alat peraga Montessori selanjutnya adalah Auto-correction (Gutek, 2004). Istilah tersebut mengandung makna bahwa setiap alat peraga Montessori memiliki pengendali kesalahan, sehingga bukan guru yang menjadi pengendali kesalahan melainkan pada alat tersebut. Misalnya saat anak menggunakan tongkat asta merah biru untuk melakukan operasi penjumlahan $2+3$. Siswa akan mengambil tongkat 2 dan meletakkan tongkat 3 diatasnya kemudian mencari tongkat yang panjangnya sama dengan gabungan kedua tongkat tersebut, maka alat tersebut memiliki pengendali kesalahan berupa panjang yang berbeda. Apabila panjang tongkat yang di dekatkan tidak sama dengan panjang tongkat yang digabungkan itu artinya salah dan kesalahan tersebut dapat diketahui sendiri oleh siswa karena dapat diamati, dirasakan dan diamati dengan pancaindra.

Konsep menarik adalah karakteristik alat peraga Montessori yang selanjutnya. Alat peraga Montessori dirancang semenarik mungkin, baik dalam hal warna, bentuk, dan cara penggunaan. Hal tersebut bertujuan untuk menarik minat siswa untuk menyentuh dan menggunakan alat tersebut. Montessori (2008) mengungkapkan bahwa setiap alat peraga harus memiliki keindahan. Anak yang tertarik dan berinisiatif sendiri untuk menggunakan alat peraga tentu akan lebih merasa senang dibandingkan dengan yang disuruh atau dipaksakan.

Alat peraga Montessori yang menarik juga dilengkapi dengan karakteristik bergradasi. Maksud dari bergradasi adalah setiap alat memiliki suatu hal yang kontras baik kontras dalam hal warna, bentuk ukuran, maupun jumlah. Hal yang kontras tersebut akan memudahkan anak untuk mengetahui perbedaannya. Selain kontras, bergradasi juga memiliki makna bertingkat dan konsisten.

Peneliti menambahkan satu karakteristik alat peraga Montessori pada penelitian ini yaitu kontekstual. Kontekstual yang dimaksud pada penelitian ini adalah alat peraga dibuat menggunakan bahan yang ada disekitar siswa, sehingga siswa lebih merasa familier serta membuat atau mendapatkannya lebih mudah. Maria Montessori juga banyak memanfaatkan barang atau bahan yang ada disekitar untuk digunakan sebagai alat peraga (Magini, 2013). 
Montessori menggunakan metode eksperimental dalam mengembangkan pembelajaran dan alat-alat peraga yang digunakan dan secara intensif selama dua tahun dikembangkan disekolahnya di Casa dei Bambini (Rumah Anak-anak) yang didirikan 1907 di Roma. Dengan metode eksperimental Montessori mengembangkan pembelajaran pertama-tama bukan berdasarkan hasil edukasi dari teoriteori pendidikan yang sudah ada dan sudah dianggap benar sebelumnya, tetapi berdasarkan induksi dari pengamatan langsung terhadap anak dan aktivitas pembelajaran dengan lingkungannya. (Montessori, 2002).

Montessori mula dengan membuat alat-alat pembelajaran yang dibuat secara paralel dengan memodifikasi bentuk dan warna yang berbeda-beda untuk satu jenis alat peraga yang sama. Alat tersebut lalu dipaparkan ke anak-anak. Jika anak-anak ternyata lebih memilih untuk menggunakan suatu alat peraga, Montessori lalu menyingkirkan semua alat peraga paralel yang tidak dipilih anak-anak. Dengan itu Montessori mendapatkan alat peraga yang memang sesuai dengan kecenderungan alamiah anak sendiri. Dengan teknik pemaparan dan eliminasi ini Montessori mengembangkan berbagai alat peraga yang lain. Dari situ Montessori menemukan benang merah yang menjadi ciri khas alat peraga Montessori.

Ciri-ciri tersebut adalah sebagai berikut (Montessori, 2002): (a) Menarik: Bagi anak-anak pembelajaran dimaksudkan untuk mengembangkan seluruh potensi anak melalui panca indera. Alatalat peraga harus dibuat lebih menarik bagi anak-anak agar secara spontan anak-anak ingin menyentuh, meraba, memegang, merasakan, dan menggunakannya untuk belajar. Untuk itu tampilan fisik alat peraga harus mengkombinasikan warna yang cerah dan lembut. Dari sisi pembelajaran sensorial menjadi basis perkembangan bagi anak-anak (Montessori, 2002); (b) Bergradasi: Alat peraga harus memiliki gradasi rangsangan yang rasional terkait warna, betuk, dan usia anak sehingga bukan hanya alat peraga sebanyak mungkin melibatkan penggunaan panca indera, tetapi juga alat peraga yang sama bsa digunakan untuk berbagai usia perkembangan anak dengan tingkat abstraksi pembentukan konsepkonsep yang semakin kompleks. Untuk memperkenalkan gradasi warna merah, misalnya, kartu-kartu warna merah dibuat dengan 10 gradasi dari kartu merah yang berwarna sangat tua sampai dengan kartu merah sangat muda. Untuk memperkenalkan gradasi bentuk, misalnya, permainan pink tower terdiri 10 kubus dengan kubus paling besar memiliki sisi 10 centimeter. Kubus yang lebih kecil berikutnya selalu memiliki ukuran kubus lebih kecil 1 centimeter. Anak akan mencoba menyusun menara mulai dengan kubus yang paling besar yang ada di posisi paling bawah sampai kubus yang paling kecil berada di posisi paling atas. Dengan itu anak belajar membeda-bedakan besar-kecil dan berat-ringan suatu objek (Montessori, 2002). Karakter penggunaan alat peraga Montessori memiliki tingkat abstraksi yang berkelanjutan ke arah yang semakin kompleks sesuai dengan perkembangan usia anak. Misalnya media binomial cube, pada area sensorial digunakan untuk membantu indra perabaan anak, tetapi dalam matematika dapat membantu memahami konsep bilagan berpangkat.

\section{METODE PENELITIAN}

Penelitian ini termasuk jenis penelitian dan pengembangan atau biasa disebut sebagai Research and Development (R \& D). R\&D adalah suatu proses atau langkah-langkah untuk mengembangkan suatu produk baru, atau menyempurnakan produk yang telah ada, yang dapat dipertanggungjawabkan (Sugiyono, 2009).

Prosedur pengembangan dalam penelitian ini mengadaptasi model penelitian dan pengembangan dari Sugiyono (2010) yang terdiri dari

10 langkah. Adapun langkah-langkah tersebut adalah sebagai berikut: (1) potensi dan masalah, (2) pengumpulan data, (3) Desain Produk, (4) validasi Desain, (5) Revisi Desain, (6) Ujicoba Produk, (7) Revisi Produk, (8) Ujicoba Pemakaian, (9) Revisi Produk, (10) Produksi masal. Dalam penelitian ini, peneliti hanya menggunakan 5 langkah penelitian dan pengembangan, yaitu (1) potensi dan masalah, (2) pengumpulan data, (3) desain produk, (4) validasi desain, dan (5) revisi desain. Berikut langkah-langkah penelitian dan pengembangan yang digunakan oleh peneliti : 


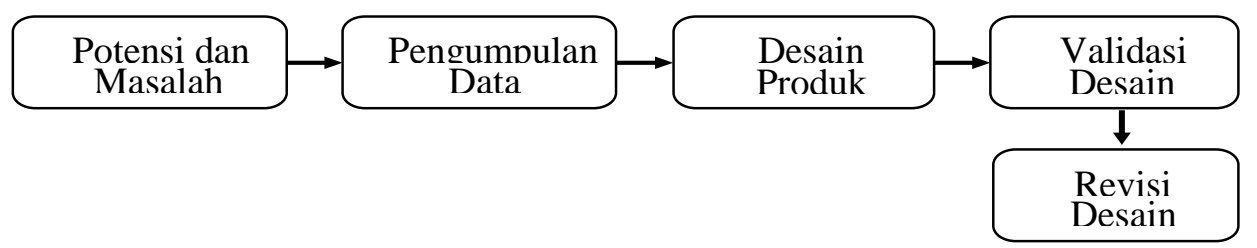

Diagram 1. Bagan penelitian dan pengembangan yang digunakan

Langkah-langkah penelitian dan pengembangan yang dilakukan peneliti dapat dijabarkan sebagai berikut:

1) Potensi dan Masalah: Dalam langkah ini, peneliti melakukan kajian di TK. Peneliti melihat potensi adanya ketersediaan buku ketrampilan hidup sehari-hari di TK, dan menjadi masalah karena buku ketrampilan hidup sehari-hari belum ada. Berdasarkan potensi yang ada, peneliti ingin melakukan mengenalkan ketrampilan hidup sehari-hari melalui buku ketrampilan hidup sehari-hari dengan menggunakan metode Montessori.

2) Pengumpulan Data: Pengumpulan data dilakukan dengan cara studi literatur, survei lapangan. Studi literatur dilakukan untuk mendapatkan informasi sebanyak-banyaknya berkaitan dengan buku yang dikembangkan. Sedangkan studi lapangan di laboratorium Montessori PGSD Universitas Sanata Dharma untuk mendapatkan informasi terkait montessori. Peneliti melakukan analisis kebutuhan, yaitu dengan melakukan wawancara terhadap guru di dua Taman Kanak-kanak (TK) di Yogyakarta dan Surakarta. Hal ini bertujuan untuk mendapatkan informasi secara lengkap dan tepat dalam buku montessori. Instrumen penelitian yang digunakan dalam penelitian ini adalah terkait dengan analisis kebutuhan dan uji validasi produk oleh ahli, guru serta siswa. Instrumen analisis kebutuhan digunakan untuk mengetahui gambaran awal yang diperoleh dari lapangan dengan menggunakan wawancara mengenai produk seperti apa yang nantinya dikembangkan.

3) Desain Produk: Berdasarkan data yang telah diperoleh dalam tahap pengumpulan data, peneliti membuat desain produk buku montessori. Buku yang dibuat merupakan album yang membantu guru maupun calon guru dalam membantu siswa mandiri dalam melakukan kegiatan ketrampilan hidup sehari-hari. Isi dari album adalah sejarah Montessori, filosofi dari Maria montessori dan ada 40 ketrampilan hidup sehari-hari yang dapat membantu guru maupun calon guru.

4) Validasi Desain. Dalam langkah ini, peneliti melakukan validasi desain dengan guru, orang yang berkecimpung dalam bidang multikultur, dan siswa SD kelas atas. Dalam validasi ini, para validator memberikan penilaian, kritik, dan sarannya terhadap desain yang telah dibuat oleh peneliti. Validator memberikan beberapa komentar dan revisi terhadap produk jika dibutuhkan. Dalam hal ini peneliti diminta untuk melakukan revisi terkait dengan album ketrampilan hidup sehari-hari. Untuk uji validitas digunakan wawancara yang ditujukan untuk ahli, guru dan siswa. Berikut peneliti paparkan tentang pengujian instrumen yang akan digunakan. Validasi untuk mengetahui kualitas produk yang peneliti kembangkan dilakukan sesuai dengan pedoman penyekoran skala lima menurut Sukardjo (2008). Tabel berikut merupakan Konversi Data Kuantitatif ke Data Kualitatif Skala Lima. Setelah data diperoleh dari responden, data dianalisis dengan statistic deskritif. Langkah-langkah analisis statistik deskritif yang dimaksud meliputi : (1) penggumpulan data, (2) Pemberian skor analisis kuantitatif, dan (3) Skor yang diperoleh melalui analisis dikonversikan menjadi nilai dengan skala lima. Tabel 1 memuat konversi nilai lima Sukardjo (2008) sebagai acuan untuk menilai kualitas atau kelayakan produk yang dihasilkan.

Tabel 1. Konversi Nilai Skala Lima (Sukardjo, 2008)

\begin{tabular}{ll}
\hline \multicolumn{1}{c}{ Interval Skor } & \multicolumn{1}{c}{ Kategori } \\
\hline$X>\overline{X_{i}}+1,80 \mathrm{Sbi}$ & Sangat baik \\
\hline$\overline{X_{i}}+0,60 \mathrm{SB}_{\mathrm{i}}<X \leq \overline{X_{i}}+1,80 \mathrm{SB}_{\mathrm{i}}$ & Baik \\
\hline$\overline{X_{i}}-0,06 \mathrm{SB}_{\mathrm{i}}<\mathrm{X} \leq \overline{X_{i}}+0,06 \mathrm{SB}_{\mathrm{i}}$ & Cukup \\
\hline$\overline{X_{i}}-1,08 \mathrm{SB}_{\mathrm{i}}<\mathrm{X} \leq \overline{X_{i}}-0,06 \mathrm{SB}_{\mathrm{i}}$ & Kurang \\
\hline $\mathrm{X} \leq \overline{X_{i}}-1,80 \mathrm{SB}_{\mathrm{i}}$ & Sangat kurang \\
\hline
\end{tabular}


Keterangan:

$$
\begin{array}{ll}
\text { Rerata Ideal }\left(\overline{X_{i}}\right) & : \frac{1}{2} \text { (skor maksimal ideal + skor minimal ideal) } \\
\text { Simpangan Baku Ideal }\left(\mathrm{SB}_{\mathrm{i}}\right) & : \frac{1}{6} \text { (skor maksimal ideal - skor minimal ideal) } \\
\mathrm{X} & : \text { Skor aktual }
\end{array}
$$

5) Revisi Desain. Revisi desain merupakan langkah terakhir dalam penelitian ini. Revisi desain dilakukan dengan memperbaiki desain yang masih terdapat kekurangan. Hal tersebut dilakukan berdasarkan komentar/saran/kritik yang diberikan oleh guru, orang yang berkecimpung dalam bidang multikultur, dan siswa. Revisi desain dilakukan untuk menyempurnakan produk, sehingga produk layak untuk digunakan.

Hasil-hasil Penelitian ini dapat dideskripsikan berdasarkan urutan pencapaian tujuan penelitian. Berdasarkan tujuan yang telah ditentukan ada dua aspek yang diungkap dalam penelitian ini. Ketiga aspek tersebut meliputi (1) prosedur pengembangan album ketrampilan hidup sehari-hari dan (2) hasil validasi dan kualitas penyusunan album kerampilan hidup sehari-hari.

\section{HASIL PENELITIAN DAN PEMBAHASAN}

\section{Prosedur Pengembangan Album Ketrampilan Hidup Sehari-hari}

Pengembangan album ketrampilan hidup sehari-hari baru melalui empat tahap penelitian yaitu potensi masalah, desain produk, instrumen uji coba, validasi produk. Potensi masalah pada tahap pertama diawali dengan analisis kebutuhan yang dilakukan oleh peneliti melalui wawancara tidak terstruktur. Wawancara dilakukan kepada guru di dua sekolah Taman Kanak-Kanak di Yogyakarta dan Surakarta. Hasil wawancaera meatakan bahwa guru membutuhkan buku panduan bagi oang tua untuk membimbing anak-anak secara mandiri.

Album didesain penuh gambar dan berwarna. Halaman sampul didesain dengan warna menarik dan diberi gambar model anak yang sedang menggunakan media.

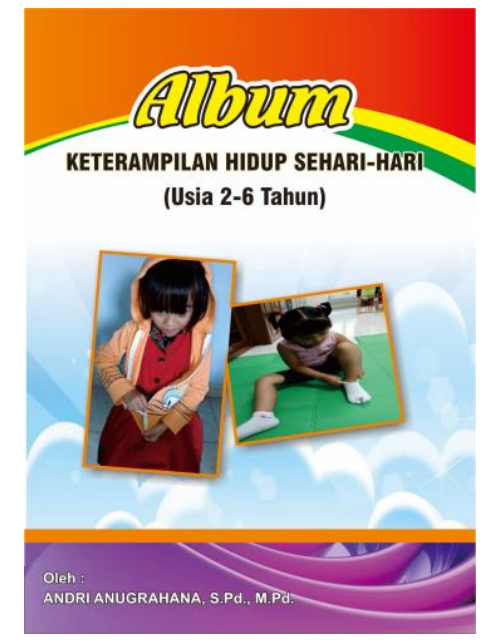

\section{Gambar 1. Sampul Album Hasil Validasi Dan Kualitas Penyusunan Album Ketrampilan Hidup Sehari-Hari}

Validasi untuk mengetahui kualitas produk yang peneliti kembangkan dilakukan sesuai dengan pedoman penyekoran skala lima menurut Sukardjo (2008:101). Tabel berikut merupakan Konversi Data Kuantitatif ke Data Kualitatif Skala Lima.

Skala penilaian terdiri dari lima pilihan untuk menilai "Media Montessori" yang dikembangkan, yaitu sangat baik (5), baik (4), cukup (3), kurang baik (2), dan sangat kurang baik (1). Rumus konversi tersebut digunakan untuk mengolah data kuantitatif menjadi data kualitatif dengan ketentuan sebagai berikut: 
Penyusunan Album Keterampilan Hidup Sehari-Hari Untuk Anak Usia 2 - 6 Tahun Berdasar Pada Metode Montessori (Andri Anugrahana)

Diketahui :

Skor maksimal ideal $\quad=5$

Skor minimal ideal $\quad=1$

Rerata ideal $\left(\overline{X_{i}}\right)$

$$
=\frac{1}{2}(5+1)=3
$$

Simpangan baku ideal $\left(\mathrm{SB}_{\mathrm{i}}\right)$

$$
=\frac{1}{6}(5-1)=0,67
$$

Ditanyakan:

Interval skor kategori sangat baik, baik, cukup, kurang dan sangat kurang baik.

Jawaban :

$$
\begin{aligned}
& \text { Kategori sangat baik } \quad=X>\bar{X}_{i}+1,80 \text { Sbi } \\
& =X>3+1,80 \mathrm{Sbi} \\
& =X>3+(1,21) \\
& =X>4,21 \\
& \text { Kategori baik } \\
& =\overline{X_{i}}+0,60 \mathrm{SB}_{\mathrm{i}}<X \leq \overline{X_{i}}+1,80 \mathrm{SB}_{\mathrm{i}} \\
& =3+(0,60 \times 0,67)_{\mathrm{i}}<X \leq 3+(1,80 \times 0,67) \\
& =3+(0,40)<X \leq 3+(1,21) \\
& =3,40<X \leq 4,21 \\
& \text { Kategori cukup } \\
& =\overline{X_{i}}-0,06 \mathrm{SB}_{\mathrm{i}}<X \leq \overline{X_{i}}+0,06 \mathrm{SB}_{\mathrm{i}} \\
& =3-(0,60 \times 0,67)<X \leq 3+(0,60 \times 0,67) \\
& =3-(0,40)<X \leq 3+(0,40) \\
& =2,60<X \leq 3,40 \\
& \text { Kategori kurang baik } \quad=\bar{X}_{i}-1,08 \mathrm{SB}_{\mathrm{i}}<X \leq \overline{X_{i}}-0,06 \mathrm{SB}_{\mathrm{i}} \\
& =3-(1,08 \times 0,67)<X \leq 3-0,06 \mathrm{SB}_{\mathrm{i}} \\
& =3-(1,21)<X \leq 3-(0,40) \\
& =1,79<X \leq 2,60 \\
& \text { Kategori sangat kurang baik } \quad=X \leq \overline{X_{i}}-1,80 \mathrm{SB}_{\mathrm{i}} \\
& =\underline{X} \leq \overline{X_{i}}-(1,80 \times 0,67) \\
& =X \leq \overline{X_{i}}-(1,21) \\
& =X \leq \overline{X_{i}}-1,79
\end{aligned}
$$

Berdasarkan perhitungan tersebut dapat diperoleh konversi data kuantitatif menjadi data kualitatif skala lima sebagai berikut:

Tabel 3. Kriteria skor skala lima

\begin{tabular}{cl}
\hline Interval Skor & Kriteria \\
\hline$X>4,21$ & Sangat baik \\
\hline $3,40<X \leq 4,21$ & Baik \\
\hline $2,60<X \leq 3,40$ & Cukup \\
\hline $1,79<X \leq 2,60$ & Kurang \\
\hline$X \leq 1,79$ & Sangat Kurang \\
\hline
\end{tabular}

Kuesioner dalam penelitian ini terdiri dari 4 Aspek yaitu tujuan dan metode, cover, isi dan bahasa. Aspek Tujuan dan metode terdiri dari 4 pernyataan yaitu (1) Pembelajaran dalam Album Montessori Ketrampilan hidup sehari-hari dibuat menarik, (2) Album Montessori ketrampilan hidup sehari-hari dibuat sesuai dengan prinsip Montessori, (3) Album Montessori Ketrampilan Hidup sehari- 
hari memberikan kesempatan guru untuk menggunakan konteks yang nyata dalam mengajar, (4) Album Montessori Ketrampilan Hidup sehari-hari membantu guru lebih kreatif. Aspek cover terdiri dari 6 pernyataan yaitu (1) Gambar sesuai dengan materi, (2) Komposisi unsur tata letak (judul, pengarang, ilustrasi, logo, dan lain-lain seimbang dan seirama dengan tata letak isi),(3) Memiliki kekontrasan yang baik (pewarnaan halaman depan). (4) Ukuran judul lebih dominan dibandingkan nama pengarang dan tulisan lainnya, (5) Judul dapat memberikan informasi secara cepat dan tepat tentang materi isi album, (6) Cover menarik. Aspek Isi terdiri dari 10 pernyataan yaitu Komponen dalam Album Montessori Ketrampilan Hidup sehari-hari lengkap, (2) Materi Album Montessori Ketrampilan Hidup sehari-hari sesuai dengan judul buku, (3) Petunjuk pada Album Montessori Ketrampilan Hidup sehari-hari jelas dan mudah dipahami, (4) Alat dan bahan yang digunakan dalam setiap kegiatan mudah disiapkan oleh guru, (5) Materi disusun secara runtut (6) Album memuat prinsip Montessori: Anak sebagai pribadi yang unik (7) Album memuat prinsip Montessori: Absorbent Mind, (8) Album memuat kprinsip Montessori: Sensitive periods, (9), Album memuat kprinsip Montessori: Lingkungan anak (10) Album memuat prinsip Montessori: Kemandirian anak

Aspek bahasa terdiri dari 4 aspek yaitu Kalimat yang digunakan singkat dan jelas, (2) Bahasa yang digunakan mudah dipahami, (3)

Bahasa yang digunakan sesuai dengan ejaan yang disempurnakan (EYD), (4) Ukuran dan bentuk huruf menarik. Tabel 4 memuat rekapitulasi rata-rata skor untuk setiap aspeknya.

Tabel 4. Rekapitulasi Hasil Validasi Ahli
\begin{tabular}{clc}
\hline No & \multicolumn{1}{c}{ Aspek } & SKOR \\
\hline 1 & Tujuan dan Metode & 3,75 \\
\hline 2 & Cover & 3,83 \\
\hline 3 & Isi & 3 \\
\hline 4 & Bahasa & 3,5 \\
\hline
\end{tabular}

\section{PEMBAHASAN}

Berdasarkan kriteria skor skala lima tersebut di atas, maka peneliti melakukan pengolahan data dari para validator. Hasil validasi dari salah satu validator yaitu kepala sekolah Montessori yang ada di Yogyakarta, berikut aspek-aspek yang dinilai:

a. Tujuan dan metode: Untuk tujuan dan metode mendapatkan skor 3,75 dalam kategori baik. Dan untuk aspek tujuan mendapatkan masukkan yaitu: aspek pertama, pembelajaran dalam Album Montessori Keterampilan hidup sehari-hari dibuat menarik tidak ada komentar. Pada aspek kedua, album Montessori keterampilan hidup sehari-hari dibuat sesuai dengan prinsip Montessori mendapat komentar bahwa dalam setiap kegiatan baik jika dicantumkan "appropriate age". Lalu pada aspek ketiga, album Montessori Keterampilan hidup sehari-hari memberikan kesempatan guru untuk menggunakan konteks yang nyata dalam mengajar mendapat komentar bahwa ada beberapa hal yang perlu diberikan dalam bentuk "simulasi" sebelum melakukan yang riil (contoh: Dressing Frames). Pada aspek yang terakhir yaitu keempat, album Montessori Keterampilan hidup sehari-hari membantu guru lebih kreatif tidak ada komentar.

b. Cover: Untuk cover mendapatkan skor 3,83 dalam kategori baik. Dan untuk aspek cover mendapatkan masukan yaitu: aspek pertama, gambar sesuai dengan materi mendapat komentar bahwa gambar anak laki-laki belum sesuai dan belum jelas apa yang dilakukan. Aspek kedua, komposisi unsur tata letak (judul, pengarang, ilustrasi, logo, dan lain-lain seimbang dan seirama dengan tata letak isi) mendapat komentar bahwa untuk usia tersebut belum bisa memakai kaus kaki sendiri. Pada aspek ketiga, memiliki kekontrasan yang baik (pewarnaan halaman depan) tidak ada komentar. Aspek keempat, ukuran judul lebih dominan dibandingkan nama pengarang dan tulisan lainnya tidak ada komentar. Lalu aspek kelima, judul dapat memberikan informasi secara cepat dan tepat tentang materi isi album juga tidak ada komentar. Begitu pula pada aspek keenam, cover menarik juga tidak mendapatkan komentar.

c. Isi. Untuk isi mendapatkan skor 3 dalam kategori cukup. Dan untuk aspek isi mendapatkan masukan yaitu: aspek pertama, komponen dalam album Montessori Keterampilan hidup seharihari lengkap mendapat komentar bahwa sudah dibantu dengan lampiran. Pada aspek kedua hingga aspek kesempuluh tidak ada komentar yang diberikan. Isi aspek tersebut yaitu, aspek kedua, materi 
album Montessori Keterampilan hidup sehari-hari sesuai dengan judul buku. Aspek ketiga, petunjuk pada album Montessori keterampilan hidup sehari-hari jelas dan mudah dipahami. Aspek keempat, alat dan bahan yang digunakan dalam setiap kegiatan mudah disiapkan oleh guru. Aspek kelima, materi disusun secara runtut. Aspek keenam, album memuat prinsip Montessori: Anak sebagai pribadi yang unik. Aspek ketujuh, album memuat prinsip Montessori: Absorbent Mind. Aspek kedelapan, album memuat prinsip Montessori: Sensitive periods. Aspek kesembilan, album memuat prinsip Montessori: Lingkungan anak. Dan yang terakhir yaitu aspek kesepuluh, album memuat prinsip Montessori: Kemandirian anak.

d. Bahasa Untuk isi mendapatkan skor 3,5 dalam kategori cukup. Dan untuk aspek bahasa mendapatkan masukan yaitu: aspek pertama, kalimat yang digunakan singkat dan jelas tidak ada komentar. Aspek kedua, bahasa yang digunakan mudah dipahami tidak ada komentar. Aspek ketiga, bahasa yang digunakan sesuai dengan ejaan yang disempurnakan (EYD) tidak ada komentar. Aspek yang terakhir yaitu keempat, ukuran dan bentuk huruf menarik mendapat komentar bahwa font lebih baik yang besar dan tidak terlalu rapat.

e. Masukan secara umum. Secara keseluruhan hasil validasai ahli menujukkan skor 3,4 dengan kriteia baik. Dan masukan secara keseluruhan adalah: 1) Sebagai buku akan sangat bermanfaat bagi orang tua atau guru karena referensi seperti ini tidak banyak dipublikasikan. 2) Sebaiknya memberikan gambaran lebih detail tentang filosofi Montessori dan program area PL. 3) Meninjau ulang kelompok usia untuk disesuaikan dengan kelompok usia sesuai tahap perkembangan Montessori. 4) Menambah kegiatan PL sesuai dengan kelompok usia dan sub kegiatannya.

\section{SIMPULAN DAN SARAN}

Simpulan bagi penelitian ini adalah: 1) Pengembangan album ketrampilan hidup sehari-hari baru melalui empat tahap penelitian yaitu potensi masalah, desain produk, instrumen uji coba, validasi produk; 2) Hasil validasi ahli menujukkan skor 3,4 dengan kriteia baik meskipun masih banyak perbaikan.

Saran bagi penelitian selanjutnya dapat dikembangkan untuk beberapa area dalam montessori yaitu area bahasa, matematika ataupun area yang lainnya, Penelitian selanjutnya agar melakukan pengumpulan data dari sekolah yang lebih banyak supaya data analisis kebutuhan yang diperoleh lebih meyakinkan dan lebih akurat.

\section{DAFTAR PUSTAKA}

Arikunto, S. (2005). Dasar-dasar evaluasi pendidikan. Jakarta, Indonesia: Bumi Aksara.

Amah, N., \& Sari, N. E. (2017). Permainan Poli Dana untuk Menumbuhkan Kecerdasan Finansial pada Anak Usia Dini. Jurnal CARE (Children Advisory Research and Education), 4(2), 33.

Dewi, N. K. A. R., Suara, I. M., \& Zulaikha, S. (2014). Metode Pemberian Tugas Berbantuan Media Konkret Kegiatan Menganyam Kertas Untuk Meningkatkan Kemampuan Motorik Halus Anak Kelompok B TK Kumara Jaya. Jurnal Pendidikan Anak Usia Dini Undiksha, 2(1).

Elytasari, S. (2017). Esensi metode Montessori dalam pembelajaran anak usia dini. Bunayya: Jurnal Pendidikan Anak, 3(1), 59-73. Diunduh tanggal 11 April 2019 https://www.jurnal.arraniry.ac.id/index.php/bunayya/article/download/2045/1516

Falahudin, I. (2014). Pemanfaatan media dalam pembelajaran. Jurnal Lingkar Widyaiswara, 1(4), 104117.

Fitriana, R., Mustikawan, A., \& Julianto, I. N. L. (2015). Perancangan Buku Interaktif Sebagai Penunjang Aktivitas Belajar Pos Paud Usia 3-4 Tahun di Kelurahan Tugu-Depok. eProceedings of Art \& Design, 2(2), 767.

Fennema-Boom, J. R. (2009). Code-scaffolding: A pedagogic code-switching technique for bilingual content instruction. The Journal of Education, 190(3), 27-35. Retrieved from http://www.jstor.org/stable/42744132 
Gutek, G.L. (2015). Montessori methode: panduan wajib untuk guru dan orangtua didik paud.Yogyakarta: Pustaka Pelajar.

Gerke, S. (2000). Global lifestyles under local conditions: The new Indonesian middle class. In B. H. Chua (Ed.), Consumption in Asia: Lifestyle and identities (pp. 135-158). New York, NY: Routledge.

Hapsari, A. E. (2017). Penerapan Model Pembelajaran Kooperatif Tipe Numbered Heads Together Berbantuan Media Interaktif Untuk Meningkatkan Aktivitas dan Prestasi Belajar Siswa. Scholaria: Jurnal Pendidikan dan Kebudayaan, 7(1), 1-9

Magini, A. P. 2013. Sejarah Montessori. Yogyakarta: Kanisius.

Mahnun, N. (2012). Media pembelajaran (kajian terhadap langkah-langkah pemilihan media dan implementasinya dalam pembelajaran). An-Nida', 37(1), 27-34.

Nurgiantoro, B. (2018). Sastra anak: pengantar pemahaman dunia anak. UGM PRESS.

Putra, D. W., Nugroho, A. P., \& Puspitarini, E. W. (2016). Game Edukasi berbasis android sebagai media pembelajaran untuk anak usia dini. JIMP-Jurnal Informatika Merdeka Pasuruan, 1(1). ejurnal.unmerpas.ac.id/index.php/informatika/article/download/7/12

Sukardjo. (2008). Kumpulan materi evaluasi pembelajaran. Yogyakarta: Universitas Negeri Yogyakarta.

Sugiyono. 2009. Metode Penelitian Pendidikan; Pendekatan Kuantitatif Kualitatif dan $R \& D$. Bandung: Alfabeta

Sugiyono. (2010). Metode penelitian pendidikan. Bandung: Alfabeta.

Umar, U. (2017). MEDIA PENDIDIKAN: Peran dan Fungsinya dalam Pembelajaran. Tarbawiyah Jurnal Ilmiah Pendidikan, 11(01), 131-144.

Widyastuti, R. S. (2011, January 14). Masih sebatas macan kertas. Kompas, 34. 